\title{
The analysis of the currently used systems related to the monitoring of the mining production process
}

\author{
Konrad Trzop ${ }^{1, *}$ \\ ${ }^{1}$ KWK Ruda ul. Halembska 160, 41-711 Ruda Śląska, POLAND
}

\begin{abstract}
In the Polish mining industry the currently used monitoring systems for production processes and safety have been analyzed. The main aim of the analysis was to demonstrate the usefulness of the monitoring systems which are being used. The scope of the analysis in question also took into account the economic aspects together with natural hazards or failures of machines and devices. The performed analysis allowed to determine the usefulness of the monitoring systems used in the Polish mining industry. This article presents a questionnaire study that determined the area of application, the level of use and the suitability of monitoring systems in the mining environment. Well-selected systems for monitoring the production process are necessary to ensure safety and comfort of work. On the basis of the conducted analyzes the operation of monitoring systems was illustrated in relation to the development of modern technologies.
\end{abstract}

\section{Introduction}

Mining in Poland is characterized by diverse working conditions and the presence of a large number of natural hazards $[3,6,21]$. In order to ensure work safety and work comfort a number of systems are used. These systems monitor natural phenomena as well as the operation of machines and devices [5]. Monitoring systems enable the visualization of the parameters necessary in the production process [2]. This feature translates into the quality of supervision over the performed works. The possibility of using modern technologies in mining plants allows to improve and facilitate the work of the management staff [13]. Monitoring systems indicate already at the initial stage the place, time and cause of an undesirable phenomenon or failure. This affects the safety [8] and psychological comfort of employees.

In order to operate in a safe and economically effective manner, mining plants are more and more often implementing and using new achievements in the field of production automation. The character of operating of mines poses many challenges and barriers in this respect such as limitations resulting from the geology itself, natural hazards, mobility of devices, telecommunications limitations and many others $[26,28]$. Acquiring real-time data

* Corresponding author: konrad.trzop.kt@gmail.com 
from systems, their common processing, interpretation and control of the entire process are necessary, even critical, conditions to ensure the safety of the crew and the optimal use of the property, energy and other means of production [14, 16, 19, 20, 31]. Operating monitoring systems are responsible for the safety of people working underground. People analyzing the work of monitoring systems are obliged to make decisions based on the data from the current state of the mining plant. The data obtained from sensors, signalling devices, information transmitted via a teletransmission network and various recorders are crucial in ensuring the safety of the mining plant $[1,4,25]$.

This article discusses the operation of selected production process monitoring systems in the Polish mining industry. Additionally, the legitimacy and influence of monitoring systems on work safety were presented. The aim of the article is to analyze modern solutions of monitoring systems in comparison with solutions used in practice.

\section{Characteristics of selected work safety monitoring systems in hard coal mining}

Control over machines, devices and threats in mining by means of monitoring systems is an important issue increasing the work safety of people employed in mining excavations. The selected security monitoring systems include:

$\mathrm{SW} \mu \mathrm{P}-3$ methanometry dispatcher support system. It is based on the management of CST-40C gas meters. Additionally, it enables data transmission to the Zefir system. The system consists of a computer of the Central Measurement Module (CMP) and a computer of the Reporting and Archiving Module (MRA). The CMP is a communication module for the CST-40C and KSP and FOD900 exchanges. MRA processes, archives and reports data and is a control room for managing the CST-40C.

The CST-40C Integrated Safety System. It is used to monitor natural hazards in a mining plant. Gas measurement units are designed to receive data from sensors installed underground and on the surface. The control panels display the measured values on the screens of the monitors, archive them and send them to the SWuP-3 system. The control panels are equipped with appropriate configuration and control software.

Hetman / T company-wide telephone communication system. It allows communication between people on the surface and employees located underground. The telephone and dispatcher communication system is implemented by means of DGT 3792Elo desktops. It enables the establishment of telephone connections between the subscriber and the dispatcher. It consists of a PC with software along with an additional monitor.

Star alarm and public address system. The system consists of a telephone exchange and 3 operator stations. STAR / SAT is operated by traffic dispatchers who have direct and immediate communication with individual underground places in the mine. The system enables dispatchers to send alarm signals.

Aramis M / E seismic system. It enables detection, digital recording and buffering of seismic quakes transmitted from the bottom of the mine and their further processing (in terms of their localization and energy calculation), visualization and archiving [11,22]. Figure 1 shows an example of a plot of a seismic tremor recorded by the Aramis program. 


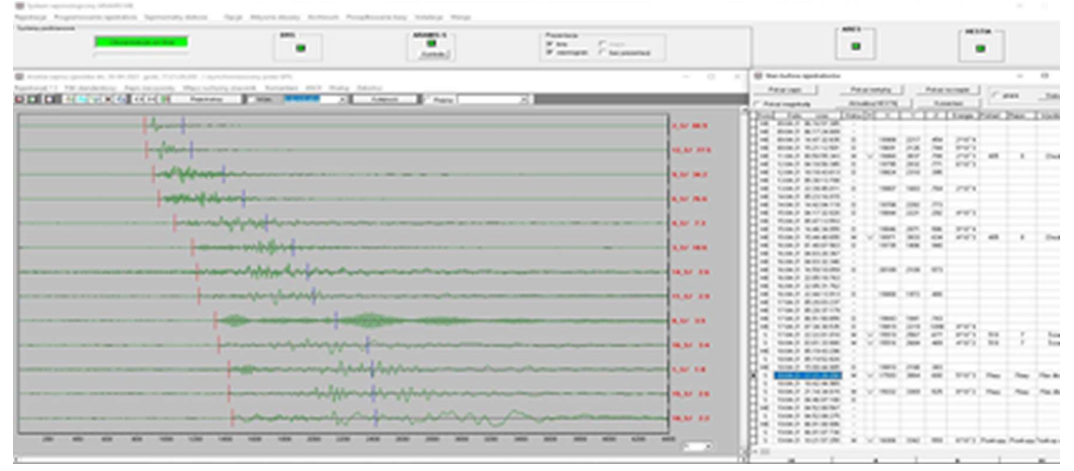

Fig. 1. Screenshot of ARAMIS seismic system.

Amax-99 soil vibration measurement system. The system registers vibration accelerations on the surface and supports works related to mining damage. Figure 2 shows an example of the vibration diagram of the Amax-99 system.

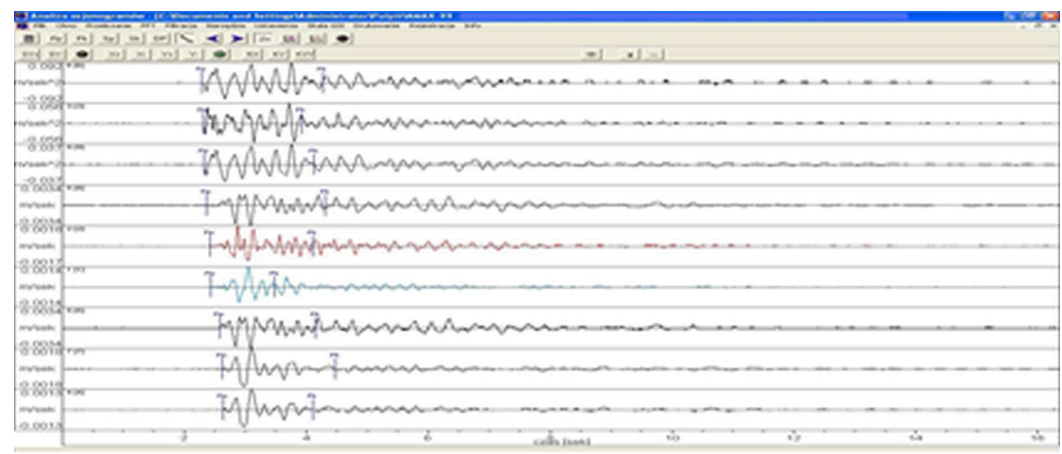

Fig. 2. Screenshot of Amax-99 seismic system

The DGT Millenium version of the KAR-DGT system is used to manage the rescue operation. The system includes the Millenium telephone exchange, digital telephones and listening devices installed in the headquarters of the rescuing action. The system is used during a rescue operation and on an ongoing basis for direct connections between selected subscribers.

\section{Characteristics of selected monitoring systems of the work production process of work in hard coal mining industry}

Monitoring of production processes supports the dispatching and mine management work enabling the forecasting of failures and the creation of analyzes of the functioning of machines and equipment in the mining plant. Some of the production process monitoring systems are:

The Zefir dispatch supervision system. It supports the work of dispatching services in the field of monitoring safety parameters and technological processes. The system consists of a master Cyklop server, mirror servers mirror and software installed on individual computers. Apart from dispatching services, access to data is also provided to designated persons in various parts of the mine. The system presents a holistic view of the information coming from all other systems available in control rooms [2]. The Zefir system (after many technical and software modifications) is still used in mines today. 
The RSPC system. It monitors the pressure in the props of powered supports. Pressure measurement is performed with the use of wireless IPS-2 type sensors attached in hydraulic connectors. The measured pressure value is directly visible in the wall and transmitted to the visualization system on the surface.

The DOH pressure monitoring system for powered support sections [5]. The system works in the form of wireless communication between pressure sensors located in the DROPS-01 powered support sections. The data obtained by the sensors are sent to the station located in the sub-wall excavation. The stand is equipped with a radio system and a cable interface to enable communication with a computer. At the sub-wall stand it is possible to see a $3 \mathrm{D}$ visualization of pressure distribution in sections of powered support and the analysis of the gathered data. Additionally, The system enables sending data to the mine surface [10, 12].

The Ek-Graf system enables the visualization of parameters and events on the haulage route on the monitor screen. In addition, the system centrally manages devices controlling the operation of conveyors and configures monitoring of devices [15, 29].

The DEMkop air conditioning monitoring and control system. The software is used to monitor the operating parameters of air-conditioning devices in hard coal mines.

The Surface Visualization System of the AT-PZW type. It is used to monitor the automation devices of the longwall complex. AT-PZW consists of devices and software enabling remote diagnostics of devices and systems as well as data archiving. The application works on workstations and enables graphic presentation of the data stored on the server.

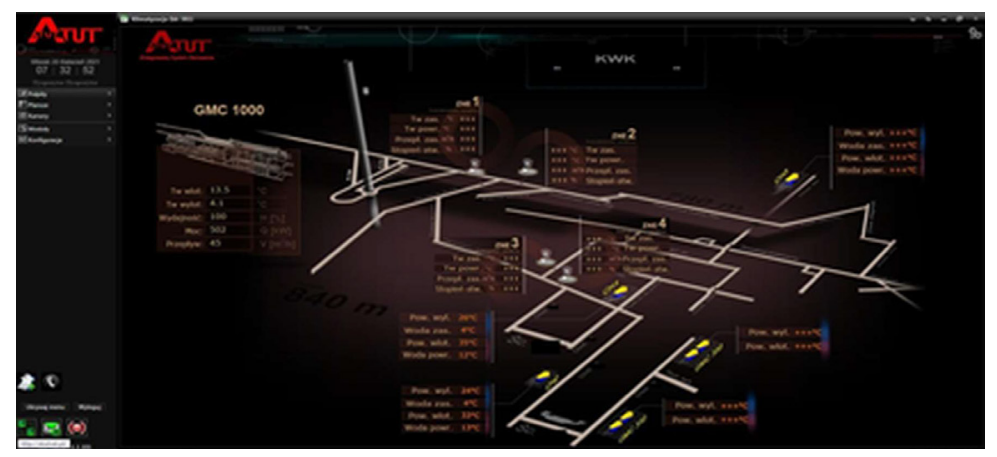

Fig. 3. Screenshot of AT-Vision2 system.

The AT-Vision2 production process support system. It supports production processes in mining plants. The system makes the results of work of machines, devices and staff available to supervising staff. The system allows you to efficiently navigate in the areas of information obtained from various devices and subsystems [2]. Figure 3 shows a 3D visualization of the location of air conditioners in mining excavations on the example of a selected mining plant.

The Asis-WaCX v.7.y.z. system. It is used to control the mine's main ventilation fan station. It is based on programmable controllers. The task of the main system is to visualize and enable control of, among others, the main fan motor, operation of pumps, subsidiary fan dampers. Moreover, the system is used to control signalling devices.

The FOD-900 multi-transmission system. It allows you to monitor electrical devices, production processes and the opening of dams. The system is based on two redundant PC class drivers, specialized communication cards and dedicated software. The data registered underground of the mine enter the system and then are properly processed and displayed on the monitor screen and the synoptic board and sent to the Zefir system. Furthermore, the 
system generates acoustic alarms that can be heard in the plant's dispatching and gasometric rooms.

\section{A survey on the degree of satisfaction of system use}

Monitoring systems are a tool used by the operator to improve safety and support technological processes. Therefore, in order to learn the opinion of employees operating systems in mining plants a survey was conducted. It had a form of a questionnaire consisting of 19 questions. Each question was provided with a closed set of answers: "yes", "no" and "no opinion". The questionnaire was given to 100 employees.

Table 1. Survey.

\begin{tabular}{|c|c|c|c|c|}
\hline \multirow[b]{2}{*}{ No. } & \multirow{2}{*}{ Question } & \multicolumn{3}{|c|}{ Answers } \\
\hline & & Yes & No & $\begin{array}{l}\text { No } \\
\text { opinion }\end{array}$ \\
\hline 1 & $\begin{array}{l}\text { Do the production monitoring systems used increase the } \\
\text { comfort of work? }\end{array}$ & 89 & 4 & 7 \\
\hline 2 & $\begin{array}{l}\text { Are the visualizations introduced in the systems of } \\
\text { emergency states of machinery and equipment clear? }\end{array}$ & 94 & 6 & 0 \\
\hline 3 & $\begin{array}{l}\text { Do the monitoring systems allow you to detect failures at an } \\
\text { early stage, according to the manufacturer's assumptions? }\end{array}$ & 73 & 21 & 6 \\
\hline 4 & $\begin{array}{l}\text { Are you in favor of introducing new technologies regarding } \\
\text { monitoring systems? }\end{array}$ & 92 & 0 & 8 \\
\hline 5 & $\begin{array}{l}\text { Have you been trained on the emergency events signalled } \\
\text { by the monitoring systems used in your workplace? }\end{array}$ & 98 & 0 & 2 \\
\hline 6 & $\begin{array}{c}\text { Does the use of such a wide range of software improve the } \\
\text { functioning of a mining plant? }\end{array}$ & 67 & 31 & 2 \\
\hline 7 & $\begin{array}{l}\text { Do monitoring sensors installed underground have a } \\
\text { negative impact on the work of the crew? }\end{array}$ & 6 & 94 & 0 \\
\hline 8 & Do the monitoring systems used make your work easier? & 98 & 0 & 2 \\
\hline 9 & Do you use innovative software more often? & 79 & 18 & 3 \\
\hline 10 & $\begin{array}{l}\text { Are you in favor of introducing more monitoring systems in } \\
\text { hard coal mining? }\end{array}$ & 88 & 8 & 4 \\
\hline 11 & $\begin{array}{l}\text { Are you in favor of standardizing one software package in } \\
\text { the entire mining company? }\end{array}$ & 76 & 23 & 1 \\
\hline 12 & Do you think the monitoring systems are intuitive? & 63 & 37 & 0 \\
\hline 13 & $\begin{array}{l}\text { Are the currently used monitoring systems made in an } \\
\text { employee-friendly manner? }\end{array}$ & 81 & 17 & 2 \\
\hline 14 & $\begin{array}{c}\text { Is the installation of sensors cooperating with monitoring } \\
\text { systems time-consuming? }\end{array}$ & 79 & 21 & 0 \\
\hline
\end{tabular}




\begin{tabular}{|c|c|c|c|c|}
\hline 15 & $\begin{array}{c}\text { Are there any training workshops on the use of monitoring } \\
\text { systems in the mines? }\end{array}$ & 46 & 54 & 0 \\
\hline 16 & $\begin{array}{c}\text { Do changing monitoring systems create problems with their } \\
\text { use? }\end{array}$ & 53 & 46 & 1 \\
\hline 17 & Do you think the mine can function without monitoring \\
systems? & 98 & 1 & 1 \\
\hline 18 & $\begin{array}{c}\text { Do the monitoring systems influence the work safety } \\
\text { factor? }\end{array}$ & 99 & 0 & 1 \\
\hline 19 & $\begin{array}{c}\text { Do the used monitoring systems allow you to react faster in } \\
\text { threat situations? }\end{array}$ & 78 & 22 & 0 \\
\hline
\end{tabular}

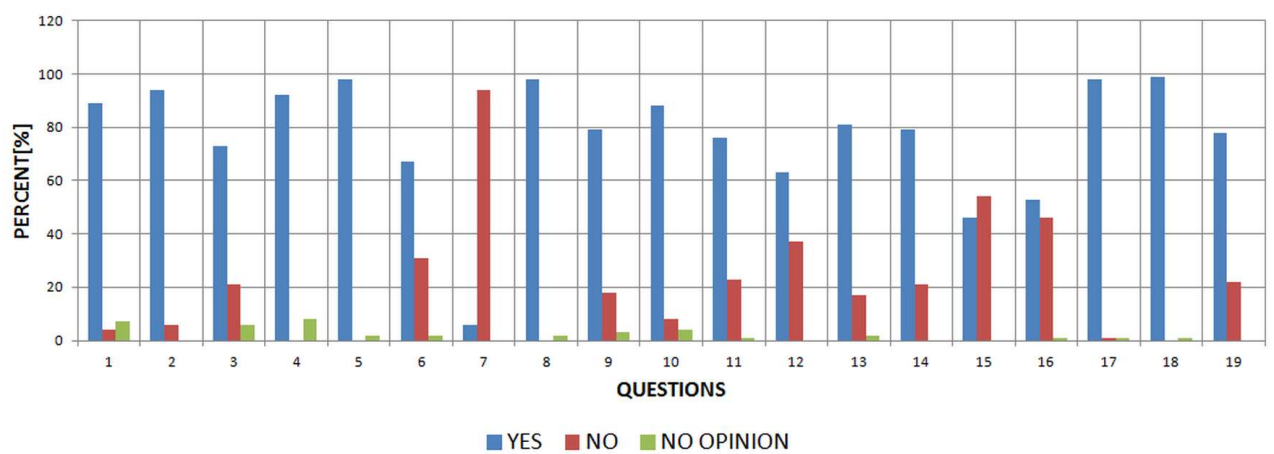

Fig. 4. The results of the survey.

The research shows that the monitoring systems are positively received by users. They increase the employees' sense of safety and comfort at work and allow them to react quickly in life-threatening situations. However, many employees are not sufficiently satisfied with the training system and the available operating instructions and manuals. Sensors placed in the mine workings do not affect the work performed and the users of the related systems believe that the functioning of the mining plant is closely related to their operation. Employees of the monitoring systems support the unification of the system in the entire company due to the reduction of the costs of purchasing software and organizing training courses. According to the employees' opinions the systems improve work and influence the development of the mining.

\section{Summary}

The analysis and questionnaire survey show that the production process monitoring systems are widely used in mining and are an indispensable element of maintaining the continuity of hard coal production. By introducing optimization packages for monitoring phenomena occurring in mining excavations and monitoring the parameters of machines and devices in real time there is a chance to reduce the accident rate and increase the level of employees' safety. Investments in installing new and in updating already existing production process monitoring systems will enable competition with other enterprises related to the energy sector. The use of systems in line with the idea of Industry 4.0 opens up opportunities for the mining industry to improve the efficiency, visualization and automation of the entire production chain. 
The monitoring systems presented in the article show the possibilities offered by modern technologies related to the monitoring of occurring phenomena in the enterprise and to what extent these systems support production processes. The benefits of using production process monitoring systems and mining hazards are invaluable. It is worth noting however that the dynamically changing conditions of works in the mining industry also require dynamic changes and updating of the monitoring systems already used.

\section{References}

1. An. Wojaczek, Ad. Wojaczek, Systemy radiowe w kopalniach. Systemy wspomagania w inżynierii produkcji (Górnictweo-perspektywy i zagorżenia, 2016)

2. An. Wojaczek, Ad. Wojaczek, Systemy monitoringu w kopalni podziemnej (Poland, 2016)

3. B. Liu, H. Sang, Z. Wang, Y. Kang, Energies, 13, 4814 (2020)

4. B. Ziętek, A. Banasiewicz, R. Zimroz, J. Szrek, S. Gola, Energies, 13, 6331 (2020)

5. D. Szurgacz, S. Zhironkin, M. Cehlár, S. Vöth, S. Spearing, M. Liqiang, Energies, 14, 697 (2020)

6. D. Szurgacz, M. Tutak, J. Brodny, L. Sobik, O. Zhironkina, Energies, 13, 17, 4538 (2020)

7. D. Szurgacz, J. Brodny, Energies, 13, 405 (2020)

8. D. Szurgacz, J. Brodny, Sustainability, 11, 2570 (2019)

9. D. Szurgacz, J. Brodny, Tests of Geometry of the Powered Roof Support Section, Energies, 12, 3945 (2019)

10. D Szurgacz, Bezpieczeństwo zmechanizowanej obudowy ścianowej w warunkach zagrożenia wstrząsami górotworu (Wiadomości Górnicze, 2017)

11. J. Wodecki, M. Góralczyk, P. Krot, B. Ziętek, J. Szrek, M. Worsa-Kozak, R. Zimroz, P. Śliwiński, A. Czajkowski, Energies, 13, 6748 (2020)

12. K. Trzop, D. Szurgacz, S. Zhironkin, A. Kasprusz, IOP Conf. Ser.: Mater. Sci. Eng. 1134 012003 (2021)

13. K. Trzop, D. Palka, D. Szurgacz, L. Sobik, IOP Conf. Ser.: Earth Environ. Sci. 684 012009 (2021)

14. K. Stańczyk, Energies, 13, 5174 (2020)

15. M. Bajda, M. Hardygóra, Energies, 14, 1512 (2020)

16. M. Beer, R. Rybár, M. Cehlár, S. Zhironkin, P. Sivák, Energies, 13, 2450 (2020)

17. M. Beer, M. Taušová, R. Rybár, M. Kal’avský, Energies, 13, 3378 (2020)

18. M.D. Mbedzi, H.M. van der Poll, J.A. van der Poll, Energies, 13, 4897 (2020)

19. M. Góralczyk, P. Krot, R. Zimroz, S. Ogonowski, Energies, 13, 6735 (2020)

20. M. Sofranko, S. Khouri, O. Vegsoova, P. Kacmary, T. Mudarri, M. Koncek, M.Tyulenev, Z. Simkova, Energies, 13, 4209 (2020)

21. M. Tutak, J. Brodny, D. Szurgacz, L. Sobik, S. Zhironkin, Energies, 13, 4891 (2020)

22. P. Boroń, J.M. Dulińska, D. Jasińska, Energies, 13, 4045 (2020)

23. P. Bortnowski, L. Gładysiewicz, R. Król, M. Ozdoba, Energies, 14, 1786 (2020)

24. P.J. Borkowski, Energies, 13, 6274 (2020)

25. P. Małkowski, Zarządzanie monitoringiem zagrożén w górnictwie (Inżyniera Mineralna, 2017) 
26. Polska Grupa Górnicza S.A., Inteligentna Kopalnia-Marcel 4.0 (2018)

27. P. Sivák, P. Tauš, R. Rybár, M. Beer, Z. Šimková, F. Baník, S. Zhironkin, J.Čitbajová, Energies ,13, 3878 (2020)

28. S. Zhironkin, A. Selyukov, M. Gasanov, Energies, 13, 3305 (2020)

29. W. Kawalec, N. Suchorab, M. Konieczna-Fuławka, R. Król, Energies, 13, 5214 (2020)

30. Y. Chen, H. Wu, H. Pu, K. Zhang, F. Ju, Y. Wu, J. Liu, Energies, 13, 2154(2020)

31. Y. Li, T. Jin, L. Liu, K. Yuan, Energies, 13, 1015 (2020) 